\title{
PENINGKATAN EKONOMI UMAT MELALUI ZAKAT PROFESI DAN ZAKAT PRODUKTIF
}

\author{
Muhtadin Dg. Mustafa*
}

\begin{abstract}
Tulisan ini merupakan sebuah kerangka pikir tentang Peningkatan Ekonomi Umat Islam melalui Pemberdayaan Zakat Profesi Dan Zakat Produktif. Pengelolaan zakat di masyarakat yang mayoritas beragama Islam memberikan keyakinan bahwa Zakat dapat digunakan sebagai instrumen penting dalam pembangunan ekonomi umat Islam. Satu hal penting lain adalah membenahi setiap UPZ (Unit Pengelolaan Zakat) yang ada agar dapat menerapkan prinsip-prinsip manajemen modern dalam pengelolaan zakat agar tercipta akuntabilitas publik dan transparansi kepada lembaga ini dapat meningkat dan mendapatkan kepercayaan dari muzakki secara terus menerus. Pemerintah dapat menggunakan sistem pengumpulan dan pengelolaan zakat sebagaimana diterapkan pada pengumpulan pajak negara, sehingga potensi zakat dapat dimanfaatkan oleh negara dan dinikmati oleh masyarakat khususnya umat Islam Indonesia. Untuk mewujudkan citacita tersebut pemerintah perlu menyiapkan petunjuk teknis tentang zakat sehingga dapat berjalan dengan baik, agar bisa lebih banyak manfaatnya dalam pertumbuhan ekonomi umat Islam di Indonesia.
\end{abstract}

Keywords: Zakat Profesi, Zakat Produktif, Ekonomi Umat

\section{A. Pendahuluan}

Fuqara, masakin dan orang yang tidak berdaya lainnya mendapat perhatian yang khusus dalam al-Quran. Dimana oleh al- 
Quran orang-orang kaya diwajibkan menyisihkan minimal 2 1/2\% dari kekayaannya sebagai zakat untuk memenuhi kebutuhan para fuqara tersebut. Zakat adalah rukun Islam ketiga setelah syahadat dan salat. Seseorang barulah sah masuk ke dalam Islam dan diakui keislamannya jika ia (bersedia) menunaikan zakatnya.

Allah swt berfirman:

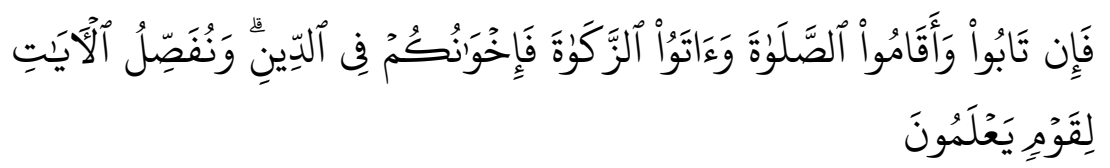

Terjemahnya :

Jika mereka bertaubat, mendirikan salat dan menunaikan zakat, maka (mereka itu) adalah saudara-saudaramu seagama. ${ }^{1}$

Ibnu Katsir dalam Muhtasar Tafsir Ibnu Katsir oleh Syah Muhammad Ali Sabuni mengomentari bahwa yang dimaksud bersih pada ayat tersebut yakni members0ihkan dosa-dosa, termasuk membersihkan jiwa dari sifat-sifat buruk seperti kikir, sombong, iri hati dan lain-lain. Hal ini karena dengan sifat-sifat tersebut hanya membuat kehancuran perekonomian umat yang pada akhirnya membuat mereka semakin sengsara.

Sedang fungsi lain dari zakat adalah sebagai pengaman dari kelaparan dan kemelaratan dan sekaligus diupayakan untuk mensejahterakan hidup mereka. Zakat adalah mutlak hak dari 8 golongan sebagaimana disebutkan dalam al-Quran:

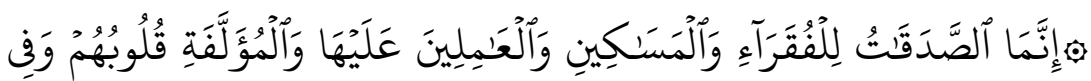

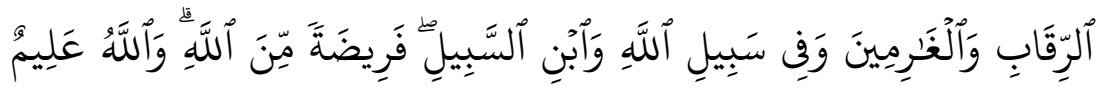

Terjemahnya :

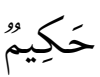

Sesungguhnya zakat-zakat itu hanyalah untuk orang-orang miskin, pengurus-pengurus zakat, para muallah yang dibujuk hatinya, untuk (memerdekakan) budak, orang-orang yang berhutang untuk jalan Allah dan orang-orang yang sedang

${ }^{1}$ Departemen Agama RI, Al-Quran dan Terjemahnya, (Semarang, Toha Putra, 1989) 297. 
dalam perjalanan sebagai suatu ketetapan yang diwajibkan Allah. Dan Allah Maha Mengetahui lagi Maha Bijaksana.. ${ }^{2}$

Dari penjelasan ayat di atas dapat dipahami bahwa zakat tidak dapat diberikan kepada selain delapan golongan yang disebut dalam ayat ini. Berbeda dengan infak $k^{3}$ dan sadaqah ${ }^{4}$ dapat dimanfaatkan untuk kepentingan lain dalam rangkan pembinaan umat.

Al-Quran dengan zakatnya mempunyai konsep yang jelas dalam meningkatkan perekonomian umat dan untuk menangani masalah kemiskinan, di samping sebagai solusi bagi disintegrasi bangsa yang disebabkan oleh jurang pemisah antara orang berduit dengan fuqara dan masakin. Sekaligus sebagai terapi bagi penyakit social baik yang disebabkan karena kekurangan harta (kemiskinan) atau bagi penyakit yang disebabkan karena bertambahnya harta,

${ }^{2}$ Ibid.

${ }^{3}$ Infaq ialah hal mendermakan harta benda di jalan Allah dengan maksud mencari pahala, seperti membangun sarana-sarana ibadah, pendidikan dan lain sebagainya. Lihat M. Abdul. Mujieb: Kamus Istilah Fiqih (Cet II, Jakarta; Pustaka Firdaus, 1995), 121. Infak juga dipahami sebagai pemberian oleh seseorang kepada orang lain guna menutupi kebutuhan, baik berupa makanan, minuman dan sebagainya; mendermakan atau memberikan rezeki (karunia) atau menafkahkan sesuatu kepada orang lain berdasarkan rasa ikhlas dan karena Allah SWT semata. Abd. Aziz Dahlan (et.al): Ensiklopedi Hukum Islam Jilid III (Cet I, Jakarta; Ichtiar Baru Van Houve, 1996), 716.

${ }^{4}$ Shadaqah diambil dari akar kata shadiqa yang artinya kejujuran atau berkata benar. Biasa juga dimaksudkan dengan sebuah pembayaran yang bersifat sukarela (berbeda dengan zakat yang bersifat wajib) untuk orang-orang yang membutuhkan, khususnya para fakir miskin. Cyril Glasse: Ensiklopedi Of Islam, diterjemahkan oleh Ghafran A. Mas'adi dengan judul "Ensiklopedi Islam (Ringkas)" (Cet III, Jakarta, Raja Grafindo Persada, 2002), 359. Kata sadaqah sesungguhnya berasal dari kata shidq yang berarti benar. Qadhi Abu Bakar bin Arabi mempunyai pendapat yang sangat berharga tentang mengapa zakat dinamakan shadaqah. Kata shadaqah berasal dari kata shidq yang berarti benar dalam hubungan dengan sejalannya perbuatan dan ucapan serta keyakinan. Bangun shad - dal - qaf bermakna "terwujudnya sesuatu oleh sesuatu, atau membantu terwujudnya sesuatu itu". Contoh di antaranya adalah shidaq "mahar" buat perempuan, yaitu terwujudnya dan diakuinya kesahan hubungan suami istri dengan diterimakannya mahar dan terlaksananya perkawinan menurut tata cara tertentu. Lihat Yusuf Al-Qardhawi: Fiqhuz Zakat, diterjemahkan oleh Salman Harun (et.al) dengan judul "Hukum Zakat" (Cet VII, Bogor; Pustaka Litera Antar Nusa, 2004), 38. 
seperti kikir, sombong, acuh terhadap lingkungan sosialnya dan lainlain.

Dengan demikian dapat dipahami bahwa betapa besar peran zakat dalam Islam yang bukan hanya sebagai pemulihan penyakit kejiwaan tetapi sekaligus sebagai perbaikan kesejahteraan umat manusia melalui pemanfaat sumberdaya yang telah disiapkan oleh Allah swt.

Upaya pemenuhan, peningkatan dan pemuasan kebutuhan manusia dalam menata kehidupannya di dunia dengan menggunakan sumber daya yang ada, adalah untuk mencapai kesejahteraan dan kemakmuran yang sebesar-besarya. Itulah simpul esensi aktivitas ekonomi. Sumber utama ekonomi di negara manapun dan dalam sistem apa pun hanya pada empat sektor, yaitu : Pertanian; Industri; Perdagangan; dan Tenaga Manusia. Selain keempat sumber tersebut, seperti pariwisata dan biaya sarana transportasi, pada dasarnya bukan merupakan sumber utama ekonomi dan belum tentu ada di setiap negara. Apabila keempat sumber di atas adapat dikelola dengan baik menurut ketentuan hukum yang berlaku, niscaya kebijakan ekonomi dalam suatu masyarakat atau negara akan menjadi baik. ${ }^{5}$

Islam, yang salah satu prinsip ajarannya tidak memisahkan kehidupan duniawi dan ukhrawi kecuali hanya membedakannya, menjadikan aktivitas ekonomi di dunia berimplikasi pula terhadap kehidupan ukhrawi. Hal itu dapat disimak, pada makna doa yang selalu dipanjatkan oleh setiap muslim dalam berbagai kesempatan, yaitu dalam QS. al-Baqarah (2) : 201. Keterkaitan doa tersebut dalam konteks ekonomi, lebih lanjut dalam QS. al-Qashash (28):77. Ayat ini memperingatkan bahwa kemakmuran dan kesejahteraan di dunia merupakan pemberian Allah swt, dan manusia akan mencapai keselamatannya jika ia dapat menggunakan kemakmuran itu dengan baik serta dapat memberi keuntungan bagi orang lain.

Secara faktual, dunia perekonomian di era global ini dikuasai oleh sistem kapitalis, yang secara telak telah melumpuhkan sistem sosialis. Kedua sistem ekonomi tersebut meskipun pada hakekatnya

${ }^{5}$ Tim Penulis Hizbut Tahrir Indonesia, Menegagkkan Syariat Islam (Cet.I; Hizbut Tahrir Indonesia, 2002), 172. 
memiliki basis falsafah yang sama, yaitu sekularisme yang karenanya menjadi "bebas nilai" (positivisme), jelas bertentangan secara diametral dengan sistem ekonomi Islam yang secara tegas memisahkan antara kepentingan duniawi dan ukhrawi. Hegemoni dan dominasi sistem ekonomi kapitalis selama ini di negara-negara berkembang tidak memberdayakan ekonomi kerakyatan, malah melahirkan kelompok konglomerat di berbagai sektor perekonomian, akibat lebih jauh, sistem perekonomian di negeri kita makin memperlihatkan ketidakadilan, yang kaya makin kaya dan yang miskin makin terpuruk dan tidak berdaya.

Islam, melalui konsep zakatnya telah memberikan andil yang cukup besar dalam upaya pemulihan ekonomi umat. Namun harus diakui bahwa hingga saat ini pengelolaan zakat sebagai potensi ekonomi umat Islam belum berjalan baik sebagaimana yang diharapkan. Hal ini terkendala pada tingkat kesadaran umat dalam membayar zakat dan sistem pengelolaan yang belum profesional.

Tulisan ini merupan hasil kajian pustaka yang dilakukan secara intensive. Dalam hal ini kami para penulis semata-mata menggunakan data sekunder melalui kajian pustaka yang mendalam terhadap berbagai literature dalam bidang kajian zakat, dan juga literature-literature yang terkait dengan konsep zakat untuk pengembangan ekonomi masyarakat. Metode kajian pustaka sudah lazim digunakan dalam melakukan suatu kajian ilmiah dalam menghasilkan sebuah karya ilmiah.

Dalam hal ini, langkah pertama yang kami lakukan adalah melakukan kajian terhadap berbagai literature dibidang zakat baik yang berupa buku teks maupun jurnal. Selanjutnya kami melakukan kajian terhadap berbagai literature dalam bidang ilmu pemberdayaan ekonomi masyarakat. Hasil kajian literatur tersebut kami kaji dan analisis untuk mengembangkan bagaimana konsep pemberdayaan berbagai jenis zakat untuk peningkatan ekonomi umat. Hasil akhir dari analisa tersebut adalah bahwa beberbagai jenis zakat dapat dimanfaatkan untuk peningkatan produktifitas ekonomi umat.

\section{B. Pembahasan}




\section{Zakat Profesi dan Zakat Produktif Untuk Peningkatan Ekonomi Umat}

Selama ini terkesan pada sebagian umat Islam bahwa persoalan ekonomi adalah sesuatu hal yang diluar kajian Islam. Padahal dalam kenyataannya manusia tidak dapat sedikit pun melepaskan diri dari aktifitas ekonomi. Tiada hari yang dilalui manusia tanpa berurusan dengan persoalan ekonomi. Dalam konteks ekonomi, tujuan akhir yang ingin dicapai manusia adalah terpenuhinya semua kebutuhan hidup (basic needs)-nya dan sekaligus meraih kesejahteraan dan kebahagiaan. Hidup yang sejahtera dan bahagia di dunia dan akhirat mustahil tercapai bila tanpa ketercukupan secara finansial dan pengamalan ajaran agama Islam secara benar dan sempurna.

Sementara itu, fitrah manusia cenderung kepada kesenangan duniawi dan kepemilikan harta benda yang banyak. Karenanya, persoalan ekonomi senantiasa menarik dan aktual dikaji sepanjang masa karena terkait dengan upaya bagaimana caranya manusia memperoleh harta kekayaan dan memanfaatkannya sebagai perhiasan kehidupan sehari-hari. Secara fitrah manusia mustahil dapat mengingkari naluri kemanusiaannya mencintai harta benda yang banyak, terpenuhi kebutuhan pangan, sandang dan papan serta aneka kebutuhan hidup lainnya.

Bahkan secara makro masalah ekonomi dapat memicu ketidakstabilan kehidupan suatu bangsa dan masyarakat. Lebih dari itu, sebagian dari negara-negara Islam di dunia termasuk dalam negara-negara miskin. Lalu kita mempertanyakan bagaimana hal ini bisa terjadi padahal al-Quran menyatakan bahwa kita umat Islam sebagai "kuntum khaira ummah". Dimanakah pembuktian kebenaran statemen al-Quran ini dalam realita kehidupan empiris?

Agama Islam menempatkan aktivitas ekonomi pada posisi strategis dalam kehidupan manusia agar mereka dapat meraih kesuksesan hidup di dunia dan akhirat kelak. Oleh karena itu, di dalam ajaran Islam ditemukan prinsip-prinsip dasar yang berkenaan dengan persoalan ekonomi. Dalam konteks ini, Islam memandang bahwa persoalan ekonomi sangatlah penting artinya bagi seorang muslim karena merupakan salah satu faktor yang dapat mengantarkan kepada 
kesejahteraan umat manusia. Dalam kaitan ini Ismail al-Faruqi menyatakan bahwa kegiatan-kegiatan ekonomi adalah pernyataan dari semangat ajaran Islam, karena ketercukupan ekonomi masyarakat dan kemakmurannya adalah cita-cita yang ingin dicapai oleh umat Islam.

Ajaran Islam tidak melarang manusia memenuhi berbagai kebutuhan hidupnya agar dalam kehidupan di dunia ini manusia dapat menikmatinya dengan sejahtera dan makmur. Kesejahteraan dan kemakmuran hidup manusia mendapat legitimasi dalam Islam asal tidak melanggar peraturan-peraturan yang digariskan agama, seperti berlaku dhalim, curang, saling memakan harta orang lain secara tidak sah ketika melakukan aktivitas transaksi ekonomi.

Secara fitrah manusia membutuhkan harta untuk memenuhi kebutuhan hidupnya, baik kebutuhan dharuriyah, hajiah maupun tahsiniyah. Untuk itu manusia berusaha mengumpulkan harta sebanyak-banyaknya agar terpenuhi segala kebutuhan hidupnya. Kebutuhan hidup manusia terus bertambah dan komplit seiring dengan terus meningkatnya populasi penduduk, teknologi dan perkembangan tingkat peradaban manusia. Untuk memenuhi segala kebutuhan hidup manusia berupaya mencurahkan segenap kemampuan dan pemikiran mencari solusi agar terpenuhi keinginannya, salah satu diantaranya melalui aktivitas ekonomi.

Salah satu fungsi zakat adalah fungsi sosial sebagai sarana saling berhubungan sesama manusia terutama antara orang kaya dan orang miskin, karena dana zakat dapat dimanfaatkan secara kreatif untuk mengatasi kemiskinan yang merupakan masalah sosial sangat akut yang harus dicarikan jalan keluar pemecahannya agar umat Islam dapat hidup layak dan terhormat sebagai manusia yang bermartabat di tengah kehidupan sosial kemanusiaan.

Dari praktik pengelolaan zakat selama ini Pemerintah telah merinci empat model pemberdayaan zakat di tanah air, yaitu :

1. Konsumtif Tradisonal

Zakat dibagikan kepada mustahik secara langsung untuk kebutuhan konsumsi sehari-hari, seperti pembagian zakat fitrah berupa beras dan uang kepada fakir miskin setiap idul fithri atau pembagian zakat maal secara langsung oleh para muzakki kepada mustahik yang 
sangat membutuhkan karena ketiadaan pangan atau karena mengalami musibah. Pola ini merupakan program jangka pendek dalam mengatasi permasalahan ummat.

\section{Konsumtif Kreatif}

Zakat yang diwujudkan dalam bentuk barang konsumtif dan digunakan untuk membantu orang miskin dalam mengatasi permasalahan sosial dan ekonomi yang dihadapinya. Bantuan tersebut antara lain berupa alat-alat sekolah dan beasiswa untuk para pelajar, bantuan sarana ibadah seperti sarung dan mukena, bantuan alat-alat pertanian seperti cangkul, gerobak jualan untuk pedagang kecil dan sebagainya.

3. Produktif Konvensional

Zakat diberikan dalam bentuk barang-barang produktif, di mana dengan menggunakan barang-barang tersebut, para mustahik dapat menciptakan suatu usaha, seperti pemberian bantuan ternak, sapi perahan, alat pertukangan, mesin jahit bordir dan sebagainya.

4. Produktif kreatif

Zakat yang diwujudkan dalam bentuk pemberian modal bergulir baik untuk permodalan proyek sosial seperti membangun sekolah, sarana kesehatan atau tempat ibadah maupun sebagai modal usaha untuk membantu atau bagi pengembangan usaha para pedagang atau pengusaha kecil.

Peran dan partisipasi umat Islam yang kaya (para aghniya) akan sangat menentukan dalam mengatasi masalah kemiskinan umat, yang antara lain melalui pendayagunaan dana zakat secara profesional dan proporsional dalam rangka pemberdayaan ekonomi umat.

Menurut Robert Chambers, pakar Pembangunan Pedesaan dari Inggeris,sebagaimana dikutip Zaki Fuad Chalil, mengatakan kemiskinan adalah adanya depriviation trap atau jebakan kemiskinan. Jebakan ini terdiri atas lima ketidakberuntungan yang melilit orang miskin, yaitu: 1). Kemiskinan itu sendiri, 2). kelemahan fisik, 3). Keterasingan, 4). Kerentanan, dan 5). Ketidakberdayaan. Kelima ketidakberuntungan ini saling terkait sehingga menyebabkan jebakan yang berkepanjangan. Kerentanan dan ketidakberdayaan merupakan dua hal yang harus diperhatikan. Kerentanan adalah ketidakmampuan dari keluarga miskin untuk menyediakan sesuatu untuk menghadapi 
situasi darurat seperti datangnya bencana alam dan wabah penyakit yang tiba-tiba menimpa keluarga tersebut. Kerentanan ini sering menjadi roda penggerak kemiskinan karena menyebabkan keluarga miskin harus menjual hartanya yang tersisa sehingga keluarga itu menjadi semakin miskin. Ketidakberdayaan membuat keluarga miskin menjadi semakin miskin, karena lemahnya posisi tawar keluarga miskin jika dihadapkan pada peraturan, kebijakan pemerintah atau kapitalis yang tidak bertanggung jawab. ${ }^{6}$

Problema sosial ini tidak hanya dapat diatasi oleh pemerintah, namun diperlukan keikutsertaan seluruh komponen masyarakat untuk menggali setiap potensi yang dimiliki bangsa. Dalam hal ini umat Islam memiliki potensi zakat, infak, shadaqah dan wakaf yang merupakan ajaran Islam dalam rangka pemberdayaan ummat.

Zakat yang merupakan salah satu rukun Islam memiliki makna strategis dalam kehidupan sosial ummat. Pada saat umat Islam menunaikan zakat sebagai implementasi kewajiban agama juga merupakan perwujudan solidaritas sosial terhadap sesama. Potensi zakat yang cukup besar perlu digali secara optimal agar dapat digunakan untuk ikut menggerakkan perekonomian ummat disamping potensi lain agar tingkat kesejahteraan ummat terangkat. Selama ini terkesan rendahnya pemahaman ummat terhadap permasalahan Zakat Produktif menjadi salah satu penyebab melambannya proses pemberdayaan Ekonomi ummat.

Pemahaman zakat produktif terus berkembang seiring dengan perkembangan pemahaman tentang zakat. Diantaranya mendayagunakan harta zakat untuk mendirikan berbagai proyek yang mendatangkan profit yang hasil akhirnya nanti akan dikembalikan kepada mustahik zakat. Secara prinsipiil boleh saja menggunakan uang zakat untuk kepentingan berbagai proyek pengembangan modal yang ada pada akhirnya menjadi milik orang yang berhak menerima zakat. Atau proyek yang dikelola oleh pihak yang berwenang

\footnotetext{
${ }^{6}$ Zaki Fuad Chalil,Wawasan Ekonomi Islam: Pemberdayaan Zakat Produktif
} Untuk Peningkatan Ekonomi Ummat http://kanazakat.blogspot.com/2011/07/zakatproduktif-wawasan.html. Diakses tanggal 17 Desember 2011 
mengumpulkan dan membagi-bagikan zakat yang tentunya setelah terlebih dahulu disalurkan sebagiannya kepada para penerima zakat yang memang betul-betul membutuhkannya dalam waktu cepat, serta dengan syarat adanya jaminan untuk tidak terjadinya kerugiankerugian.

Dalam beberapa ayat al-Qur'an ditemukan agar nasib orang fakir miskin itu diperhatikan, karena itulah diantara misi agama Allah itu diturunkan ke atas dunia ini. Allah swt berfirman(QS. Al-Haji : 28):

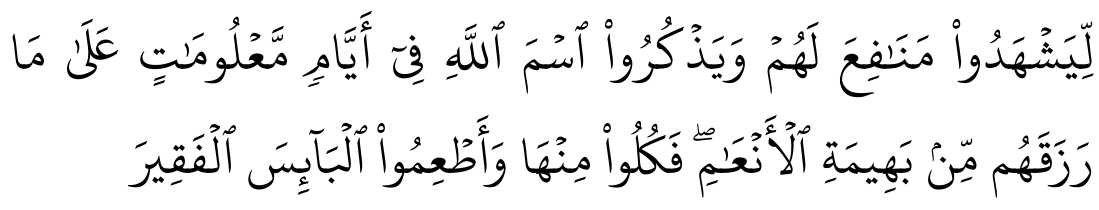

Terjemahnya:

Supaya mereka mempersaksikan berbagai manfaat bagi mereka dan supaya mereka menyebut nama Allah pada hari yang telah ditentukan atas rezeki yang Allah telah berikan kepada mereka berupa binatang ternak. Maka makanlah sebagian dari padanya dan (sebagian) lagi berikan untuk dimakan orang-orang yang sengsara lagi fakir. ${ }^{7}$

Ayat tersebut di atas menunjukkan bahwa orang-orang faqir yang sengsara itu harus diperhatikan. Kefakiran itu perlu diperangi dan dihilangkan, karena bisa merusak iman (aqidah), sebagimana sabda Nabi saw. "Kefakiran itu dekat sekali dengan kekufuran".

Ayat mengenai orang miskin di kemukakan juga dalam pada Q.S. Al-Isra' 26 :

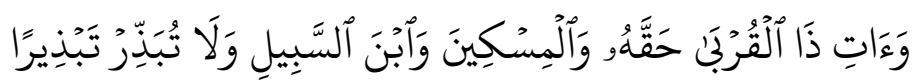

Terjemahnya:

Dan berikanlah kepada keluarga-keluarga yang dekat akan haknya. Kepada orang miskin dan orang yang dalam

${ }^{7}$ Departemen Agama RI, Al-Quran dan Terjemahnya, (Semarang, Toha Putra, 1989), 516. 
perjalanan. Dan janganlah kamu menghambur-hamburkan (hartamu) secara boros. ${ }^{8}$

Masih banyak lagi ayat-ayat lain yang pada dasarnya sangat peduli dan sangat mementingkan nasib orang yang melarat. Sebagaimana halnya kefakiran, maka kemiskinanpun perlu diperangi dan dihapuskan dengan berbagai cara yang telah diisyaratkan oleh alQur'an. Isyarat tersebut antara lain melalui peran zakat. Peran zakat dalam mengentaskan kemiskinan adalah peran yang tidak bisa dipungkiri keberadaannya, baik dalam kehidupan muslim ataupun dalam kehidupan lainnya. ${ }^{9}$

Jalan yang bisa ditempuh adalah menyantuni mereka dengan memberikan dana (zakat) yang sifatnya konsumtif atau memberikan modal yang sifatnya produktif untuk diolah dan dikembangkan. Anakanak yatim yang belum bisa berusaha dan mandiri, orang jompo atau orang dewasa yang tidak bisa bekerja karena sakit atau cacat, maka zakat konsuntif tidak bisa dihindari, mereka wajib disantuni dari sumber-sumber zakat dan infaq lainnya. Lain halnya dengan yang kuat bekerja dan bisa mandiri dalam menjalankan usaha, maka hal tersebut dapat ditempuh dengan memberi modal kepada perorangan atau kepada perusahaan yang dikelola secara kolektif.

Pemberian modal kepada perorangan harus dipertimbangkan dengan matang oleh amil. Apakah yang bersangkutan mampu mengolah dana yang diberikan itu, sehingga pada suatu saat tidak lagi menggantungkah hidupnya kepada orang lain, termasuk mengharapkan zakat. Apabila hal ini dapat di kelola dengan baik atas pengawasan dari Amil maka secara berangsur-angsur orang tidak punya akan terus berkurang dan tidak tertutup kemungkinan, dia bisa menjadi muzakki atau pemberi zakat dan bukan lagi sebagai penerima zakat.

\footnotetext{
${ }^{8}$ Ibid., 428.

${ }^{9}$ Yusuf al-Qardhawy, Dauru al-Zakāt fì 'Ilāj al-Musykilāt al-Iqtișādiyah, diterjemahkan oleh Sari Narulita dengan judul "Spektrum Zakat dalam Membangun Ekonomi Kerakyatan”, (Cet, I, Jakarta, Zikrul Hakim, 2005), h, 29
} 
Apabila usaha itu dikelola secara kolektif, maka orang-orang fakir miskin yang mampu bekerja menurut keahliannya masingmasing dapat diikut sertakan.

Dengan demikian biaya hidup sehari-hari dapat diambil dari usaha berama itu. Apabila usaha itu beruntung, maka mereka menikmati hasilnya secara bersama-sama. Hal ini memerlukan manajemen yang tertaur dan rapi. Sebagai pimpinannya dapat ditunjuk dari kalangan orang-orang yang tidak mampu itu atau ditunjuk dari kalangan orang-orang yang tidak mampu itu atau ditunjuk orang lain yang ikhlas beramal membantu mereka. Apabila hal ini ditangani dengan sungguh-sungguh, maka insya Allah akan berhasil dan tidak lagi menjadi beban bagi anggota masyarakat.

Zakat adalah fardu ain atas tiap-tiap muslim yang telah memenuhi syaratnya. Kewajiban zakat adalah berdasarkan al-Qur'an, Hadis dan Ijmak umat (kesepakatan seluruh umat Islam). Perkataan zakat disebutkan di dalam al-Quran sebanyak 82 kali dan selalu dirangkaikan dengan shalat. Ini menunjukkan pentingnya lembaga zakat itu setelah lembaga shalat yang merupakan sarana komunikasi utama antara manusia dengan Tuhan. ${ }^{10}$

Pembayar wajib zakat adalah setiap muslim yang memiliki satu nisab dari salah satu jenis harta yang wajib di zakati. Satu nisab harta adalah jumlah minimal harta benda yang dimiliki, dan jumlah nisabnya tergantung pada jenis harta benda yang dimiliki. Jenis harta yang wajib dizakati adalah Emas, Perak, hasil tanaman, buah-buahan, barang-barang pedagang, binatang ternak, barang tambang dan barang temuan dari harta terpendam. ${ }^{11}$

Zakat diatas disebut zakat maal. Zakat maal adalah zakat harta benda yang telah cukup memenuhi syarat. Sedang zakat fitrah atau zakat badan adalah zakat yang dikeluarkan setiap warga miskin sehubungan dengan selesainya melaksanakan ibadah puasa. Ajaran zakat selain bernilai ibadah, juga bernilai sosial. Hasil zakat sesungguhnya dapat didayagunakan untuk kepentingan luas sebab dari

${ }^{10}$ Muhammad Daud Ali, Sistem Ekonomi Islam, Zakat dan Wakaf, (Cet, I, Jakarta, Universitas Indonesia (UI-Press), 1988) 9.

${ }^{11}$ M. Hasbi Ash-Shiddieqy, Hukum-Hukum Fiqih Islam yang Berkembang dalam Kalangan Ahlus Sunnah, (Cet, VI, Jakarta, Bulan Bintang, 1986) 135 
memberi bahan makanan kepada fakir miskin sehingga membuka kesempatan kerja agar si miskin dapat berswadaya. Dari membangun Madrasah sekolah hingga memberikan beasiswa bagi pemuda pemudi yang cerdas tetapi kekurangan biaya. Dari membebaskan mereka yang tercekik hutang hingga menyantuni mereka yang bergerak diberbagai lapangan juang.

Zakat fitrah dapat diinfestasikan dengan syarat bahwa kebutuhan primer orang-orang fakir miskin di seluruh Indonesia pada hari idul fitri telah dicukupi dari sebagian pengumpulan zakat fitrah. Modal dan keuntungan perusahaan yang didirikan dari hasil Zakat fitrah dipergunakan untuk asnaf yang ada dan syiar Islam. ${ }^{12}$

Pengumpulan dan pembagian zakat fitrah serta penginvestasiannya diatur dan dilakukan oleh pemerintah. ${ }^{13}$ Pemerintah menjamin dan bertanggung jawab terhadap keselamatan modal dan kelebihan yang diperoleh dari zakat fitrah. Sebagaimana yang dijelaskan sebelumnya bahwa tiap-tiap harta benda atau kekayaan dikenakan zakat apabila mencapai nisab dan haulnya. Demikian juga semua bentuk pendapatan atau penghasilan dari perusahaan jasa profesi atau gaji karyawan diwajibkan zakat. Zakat dapat dibayarkan setelah habis haul atau perbulan pada saat penerimaan gaji tersebut.

Zakat berperan membantu, mengurangi dan mengangkat kaum fakir miskin dari kesulitan hidup dan penderitaan mereka. Membantu memecahkan permasalahan yang di hadapi oleh algharimin, ibnu sabil dan para mustahik lainnya. Membina dan merentangkan tali solidaritas (persaudaraan) sesama umat manusia. Mengimbangi ideologi kapitalisme dan komunisme. Menghilangkan sifat bakhil dan loba pemilik kekayaan dan penguasa modal. Menghindarkan

${ }^{12}$ Zulkifli M, Peranan Zakat dan Wakaf Dalam Peningkatan Ekonomi Umat Di Indonesia, http://prodibpi.wordpress.com/2010/08/05/ Diakses Tanggal, 17 Desember 2011

${ }^{13}$ Dalam Bab I pasal 3 Undang-Undang No 38 Tahun 1999 Tentang Zakat dikatakan bahwa pemerintah berkewajiban memberikan perlindungan, pembinaan dan pelayanan kepada muzkki, mustahiq dan amil zakat. Lihat Sekretariat Negara RI, Undang-Undang No 38 Tahun 1999 Tentang Zakat, (Cet, V, Bandung, Citra Umbara, 2010), 2 
penumpukan kekayaan perseorangan yang di kumpulkan di atas penderitaan orang lain. Mencegah jurang pemisah kaya miskin yang dapat menimbulkan malapetaka dan kejahatan sosial. ${ }^{14}$

Mengembangkan tanggung jawab perseorangan terhadap kepentingan masyarakat dan kepentingan umum. Mendidik untuk melaksanakan disiplin dan loyalitas seseorang untuk menjalankan kewajibannya dan menyerahkan hak orang lain.

Kesadaran umat Islam yang makin tinggi untuk bersama-sama pemerintah ikut serta memecahkan masalah-masalah sosial kemasyarakatan. Kehendak masyarakat membantu di bidang pendidikan, pembinaan remaja, mengatasi masalah kependudukan, memajukan program perbaikan gizi masyarakat, perbaikan lingkungan hidup. Bahkan keinginan membantu di bidang perbaikan saranasarana fisik seperti jalan dan jembatan.

Di samping pembangunan fisik yang tradisional seperti mesjid dan madrasah. Keinginan-keinginan seperti ini tumbuh wajar sebagai akibat dari kesadaran masyarakat makin meningkat, oleh upaya pemerintah yang terus menerus mengajak partisipasi rakyat, maupun dorongan oleh para pemimpin agama sendiri. Dan karena terbatasnya dana bantuan pemerintah, maka masyarakat kemudian menoleh kepada potensi yang di anggap masih belum di gali dan bahkan di wajibkan oleh agama adalah zakat.

Lebih dari itu dorongan menunaikan ibadah zakat seharusnya juga di pupuk, karena harapan kebaikan-kebaikan yang dapat di timbulkannya. Di dalam sejarah agama Islam di turunkannya syariat zakat antara lain bertujuan memelihara manusia dari kehinaan dan kemelaratan. Menguatkan persatuan dan kesatuan umat manusia karena di tumbuhkannya solidaritas sosial secara nyata dan terus menerus. Membantu memperlancar tugas-tugas untuk kepentingan umum atau masyarakat luas. Membersihkan kekayaan dalam arti secara nyata menunaikan fungsi sosial dari harta kekayaan. Menolong orang-orang berhutang yang tidak mampu membayar untuk mengurangi ketegangan dan perselisihan di dalam masyarakat.

${ }^{14}$ Yusuf al-Qardhawy, Spektrum, 41-52. 
Mengurangi terjadinya akumulasi kekayaan pada beberapa orang/kelompok dan membersihkan dari sifat rakus dan kikir.

Usaha-usaha merealisir pengembangan zakat dewasa ini terus berkembang. Antara lain dilakukan oleh pemerintah Daerah/Propinsi Daerah Khusus ibu kota Jakarta, Jawa Barat, Daerah Istimewah Aceh, Sulawesi Selatan, Sulawesi Tengah dan beberapa Propinsi lainnya di Indonesia.

Hal ini semua yang mendorong umat Islam Indonesia untuk menetapkan dan mengembangkan pelaksanaan zakat secara lebih merata lagi. Baik di dalam rangka menunaikan ajaran agama maupun untuk lebih kongkrit menunjukkan peran sertanya di dalam programprogram pembangunan nasional yang dilaksanakan pemerintah berupa pemecahan masalah kemiskinan, perbaikan lingkungan hidup, mencerdaskan kehidupan bangsa, penyediaan sarana pendidikan dan peribadatan lainnya.

Upaya merealisir pemanfaatan zakat yang dilakukan oleh pemerintah daerah yaitu dengan memanfaat jumlah dana zakat tersebut yang dikelola dan didistribusikan kepada mustahiq sesuai dengan hukum Islam dan peraturan yang berlaku. Untuk pendistrusian dana zakat yang dikelola oleh Badan Amil Zakat Daerah, dilakukan dengan tiga bentuk:

Pertama, pendistribusian dana zakat untuk mustahiq konsumtif. Untuk pendistribusian ini pun terbagi yaitu pembagian dana konsumtif untuk UPZ yang ada pada Dinas Instansi Hal ini berdasarkan jumlah mustahiq yang ada di dinas instansi pada masingmasing dinas intansi tersebut. Dengan cara dinas instansi yang ada UPZ nya mengajukan nama-nama bagi mustahiq yang ada pada dinas mereka masing-masing.

Kedua, pendistribusian oleh Badan Amil Zakat Daerah (BAZDA) kepada mustahiq non UPZ yaitu diberikan kepada masyarakat berdasarkan hasil seleksi dan nama-nama yang diberikan dari UPZCAM kemudian diseleksi oleh BAZDA.

Ketiga, pendistribusian dana zakat diberikan kepada mustahiq yang produktif yaitu dana tersebut dijadikan modal usaha oleh para mustahiq tersebut. Pendistribusian untuk mustahiq yang produktif 
untuk periode pertama ini, diberikan kepada mustahiq yang ada di UPZ yang telah dibentuk, juga kepada mustahiq yang ada di kecamatan. Untuk mustahiq yang produktif masing-masing mereka mendapatkan jumlah zakat yang berbeda, yaitu sesuai dengan kemempuan dana zakat yang terkumpul. Dana ini diberikan untuk membantu : Pedagang kecil dipasar, Pedagang gerobak, Tukang becak dan usaha kecil lainnya.

Keempat, pendistribusian Dana zakat oleh BAZDA disebut dengan dana isedentil, atau tanggap darurat. Dana ini diberikan sewaktu-waktu diperlukan oleh para mustahiq yang benar- benar memerlukannya, seperti diberikan kepada para mustahiq yang memerlukan bantuan untuk kesehatan.

Untuk pendayagunaan hasil zakat untuk usaha yang produktif ini sesuai dengan Keputusan Menteri Agama No 5 tahun 1999 BAB V pasal 28 ayat 2 yaitu: Mendayagunakan hasil zakat untuk usaha yang produktif dilakukan berdasarkan persyaratan sebagai berikut:

(1) Apabila pendayagunaan zakat sebagaimana yang dimaksud dalam ayat (1) sudah terpenuhi dan ternyata masih terdapat kelebihan.

(2) Terdapat usaha-usaha nyata yang berpeluang menguntungkan

(3) Mendapat persetujuan tertulis dari dewan Pertimbangan.

Pendayagunaan dan pendistribusian ZIS yang terkumpul didayagunakan untuk mustahiq sesuai dengan ketentuan Agama yaitu:

(1) Fakir

(2) Miskin

(3) Amil Zakat

(4) Muallaf

(5) Pemerdekaan Budak (riqab)

(6) Orang-orang yang berhutang (gharimin)

(7) Untuk Jalan Allah

(8) Orang-orang yang dalam perjalanan (ibnu Sabil)

Agar zakat mampu memberi pengaruh signifikan terhadap perekonomian masyarakat, maka potensi zakat di sebuah daerah harus dioptimalkan. Pendistribusian zakat sebaiknya diprioritaskan untuk membangun usaha produktif bagi penerima zakat yang mampu 
mendatangkan pendapatan bagi mereka dan bahkan menyerap tenaga kerja. Dengan kata lain, pendistribusian zakat haruslah direkonstruksi dari pola konsumtif menuju pola produktif. Ini dimaksudkan untuk meningkatkan kemampuan fakir miskin dalam menciptakan pendapatan dan mengeluarkan dirinya sendiri dari perangkap kemiskinan. Sehingga, zakat dapat digunakan untuk membiayai berbagai kegiatan latihan ketrampilan produktif. Kalau tidak, maka penerima zakat akan bersikap pasif, sehingga sulit diharapkan terjadi perubahan-perubahan mendasar di kalangan mereka dalam rangka memberdayakan kelompok ekonomi lemah.

Memultifungsikan zakat di sektor produktif ini selaras dengan cerita seorang masyarakat yang mengadu kepada Rasulullah karena kemiskinan, kemudian Rasulullah menyarankan kepada orang tersebut untuk menjual harta bendanya (selimut) untuk membeli sedikit makanan dan sebuah "kampak". Dengan kampak itulah, orang tersebut mencari rezeki; mencari kayu bakar dan kemudian menjualnya di pasar. Begitu pula dengan zakat, hendaklah digunakan sebagai "kampak" atau "pancing" untuk mendapatkan pendapatan, bukan semuanya untuk dikonsumsi (dihabiskan).

Zakat adalah potensi ekonomi dan sumber dana yang amat besar yang berasal dari masyarakat Islam sendiri. Potensi ekonomi yang masih terpendam ini perlu digali dan dikembangkan untuk membiyai aneka sektor pembangunan seperti sosial, pendidikan, mental dan peningkatan produktivitas.

\section{Analisis Prospektif Zakat Profesi dan Zakat Produktif}

Pertahanan ekonomi kapitalisme saat ini hanya terletak pada teknologi. Jika teknologi sudah tidak lagi memihak kepada mereka, niscaya runtuhlah hegemoni ekonomi mereka itu. Sedangkan Islam mempunyai pertahanan ekonomi kuat dan bervariasi, jika betul-betul diseriusi. Salah satunya adalah zakat. Maka zakat adalah salah satu pilar ekonomi umat Islam masa depan.

Saat ini umat terbelit oleh sistem ekonomi Kapitalisme, di mana sistem riba telah menjadi denyut nadinya. "Riba saat ini menjadi nyawa sistem ekonomi konvensional". Dampak negatif riba sangat 
banyak sekali terhadap perekomia, antara lain: penyebab tingginya inflasi dan semakin turun tingkat investasi; konsentrasi kekayaan pada segelintir kelompok; dan aspek-aspek negatif lainnya. Dengan demikian betapa dahsyat kekuatan ekonomi riba ini menghisap kekayaan masyarakat. Misalnya suatu perusahaan A meminjam uang 1 Milyar kepada Bank B dengan bunga 10\%. Setelah 10 tahun A harus mengembalikan 1.1 Milyar kepada B. Pebisnis yang baik tentunya tak mau dirugikan. Maka bunga dimasukkan ke komponen produksi sehingga harga barang akan naik juga. Artinya, masyarakat konsumen itu harus membayar beban bunga yang dibebankan kepada barang. Kalau setiap barang yang kita pakai melalui proses investasi riba seperti itu, maka ada berapa juta barang, ada berapa juta transaksi dalam sehari? Lalu ada berapa biaya yang diserap oleh sistem bunga ini dalam sehari. Kalau satu transaksi 10 cen bunga, misalkan, maka kalau sehari ada 1 juta transaksi di dunia ini, berarti 1 juta x 10 cen bunga yang dihisap dari masyarakat oleh pemilik modal. Inilah penyebab utama ketimpangan ekonomi saat ini. ${ }^{15}$

Untuk menghadapi tantangan dahsyat ekonomi konvensional ini, maka zakatlah salah satu yang paling representatif menjawabnya. Alasannya karena, zakat adalah salah satu rukun yang mempunyai keistimewaan sendiri. Hanya zakatlah yang secara eksplisit disebutkan oleh Allah yang mempunyai kepengurusan, dimana ibadah lain tidak memilikinya. Zakatlah yang hanya mempunyai petugas khusus yang biasa disebut amil. Posisi amil, sangat strategis. Kalau diperhatikan, dalam konteks amil dan kaitannya dengan ekonomi umat, al-Quran menampilkan suatu yang aktual. Betapa tidak, al-Quran menyebutkan sistem institusi lembaga untuk pengelolaan zakat.

BAZDA juga berfungsi menggali potensi masyarakat dalam meningkatkan kesejahteraan masyarakat. Dalam upaya pengentasan kemiskinan serta mensosialisasikan kewajiban zakat kepada masyarakat agar potensi zakat dapat diberdayakan secara produktif.

\footnotetext{
${ }^{15}$ Lihat Irfan Syauqi Beik, sebagaimana dikutip oleh Ahmad dalam Zakat Salah Satu Pilar Perekonomian Umat Masa Depan, http://masdimyati.multiply.com/journal/item/1/?\&show_interstitial=1\&u=\%2Fjournal \%2Fitem
} 
Kenyataan yang ada, sebagaimana di Indonesia pada umumnya, zakat yang diterima BAZDA tidak signifikan dengan jumlah masyarakat muslim yang ada. Kecilnya dana yang diterima bukan hanya disebabkan oleh karena kurangnya pengetahuan masyarakat tetapi juga karena rendahnya kepercayaan masyarakat untuk membayarkan zakat melalui BAZ.

BAZDA harus membuat formula baru mengenai pendistribusian dana zakat di wilayah hukumnya. Sebelumnya proses distribusian zakat dikelola secara konsumtif hanya bersifat sesaat dan sementara, oleh karena itu, agar zakat yang terkumpul terasa manfaatnya bagi para mustahiq dan dapat dikembangkan lagi maka dana zakat tersebut dikelola secara produktif. Pengelolaaan zakat secara produktif umpamanya diberikan keterampilan kepada pada mustahiq, diberikan modal tambahan kepada para mustahiq, yang akan dikelola oleh para mustahiq tersebut, dengan perjanjian apabila perdagangan dan keterampilan mereka sudah memadai maka modal tersebut dikembalikan kepada BAZDA, dan BAZDA akan menggulirkannya lagi kepada mustahiq yang lain.

Pertanyaannya kemudian, mengapa harus dengan institusi?, ilustrasinya bahwa secara makro, jika zakat dikelola melalui institusi lembaga, efeknya sangat luar biasa. Perekonomian akan berkembang. Salah satu sebab kenapa perekonomian dunia bertahan dan menghegemoni saat ini adalah karena mempunyai institusi keuangan yang profesional.

Akumulasi kapital sejak awal tahun 1900 hingga sekarang, jika dibandingkan dengan sebelm tahun 1900 sampai kepada Nabi Adam sekalipun, ternyata periode yang singkat ini akumulasi kapitalnya jauh lebih tinggi dari pada jutaan tahun sebelumnya. Hal itu disebabkan karena pengelolaan uang sekarang menganut "indirect financial system", atau sistem pembiayaan tidak langsung; ada lembaga pengelola keuangan, yakni Bank. Ketika uang dihimpun, kemudian bisa dimobilisasi dalam suatu mekanisme intitusi, dan bisa melakukan investasi-investasi sektor rill, maka inilah yang menjadi kekuatan dan penggerak ekonomi. Makanya, amil dalam konteks ini bisa dimanifestasikan sebagai penggerak ekonomi umat, kekuatannya 
akan luar biasa. Apalagi kalau dilakukan secara amanah dan profesional.

Apa strategi yang perlu dibuat? Paling tidak ada beberapa strategi. Antara lain, optimalisasi sosialisasi zakat, membangun citra lembaga zakat yang amanah dan profesional, membangun SDM-nya, membangun database mustahik dan muzakki secara nasional, menciptakan standarisasi mekanisme kerja lembaga zakat, dan membangun sistem zakat nasional yang mandiri dan profesional.

Jika strategi ini bisa dimaksimalkan, maka dapat dibayangkan geliat ekonomi umat Islam akan bisa mengimbangi ekonomi konvensional, bahkan justru mengunggulinya. Karena pada kenyataannya, kekuatan ekonomi konvensional saat ini terletak pada teknologi. Ekonomi mereka tegak karena teknologi sedang ada di pihak mereka. Begitu teknologi nantinya, secara lambat laun tidak lagi berpihak kepada mereka, maka ekonomi mereka juga akan goyah. Sementara pertahanan ekonomi Islam, dengan zakat saja bisa menandingi dan bahkan mengalahkan hegemoni ekonomi konvensional, jika itu dipahami secara betul dan dilaksanakan secara ikhlas serta profesional.

Itu baru zakat saja yang mempunyai dampak yang sangat luar biasa, belum lagi instrumen-instrumen lainnya yang belum dikemukakan di sini. Artinya, Islam melalui al-Quran dan hadis-nya, sebenarnya telah memberikan solusi masa depan kepada umat ini dalam bidang ekonomi. Bahkan, menurut kesimpulannya, di pintu inilah sekarang lagi terbuka kepada kita untuk ambil peran dalam membangun masa depan umat; karena ini yang paling mudah dan memungkinkan dan mudah untuk menyampaikan dakwah saat ini. Masa depan masih ada di hadapan umat Islam. Hanya, mau tidak umat ini ikut ambil bagian dalam mencapainya. Jawabannya ada pada kita semua.

Selanjutnya, untuk memberdayakan zakat di masyarakat sebagai upaya peningkatan ekonomi umat Islam ke depan maka perlu memperhatikan enam Langkah Pemberdayaan Ekonomi Bagi Mustahiq Zakat agar program pemberdayaan zakat profesi dan zakat produktif dapat direalisasikan secara terarah dan tepat sasaran, maka penyusunan program pemberdayaan masyarakat harus didasarkan 
pada kondisi objektif sasaran. Pekerjaan ini sangat penting dilakukan agar kita dapat menyusun program tentang apa saja yang dibutuhkan oleh masyarakat (mustahik zakat).

1. Pemetaan Masalah berupa analisis sosial, ekonomis, teknis dan kelembagaan sebagai langkah awal untuk identifikasi permasalahan. Dengan cara ini akan terhimpun data awal tentang apa yang dibutuhkan dan diinginkan oleh masyarakat.

2. Melakukan analisis pihak terkait (stakeholders) langkah ini bertujuan untuk menjajaki kepentingan, pengaruh dan tingkat partisipasi pihak terkait yang dapat dipengaruhi dan berpengaruh pada pelaksanaan program pemberdayaan.

3. Membuat rancangan dan desain yang logis dan sesuai dengan kebutuhan kelompok sasaran serta wilayah sasaran.

4. Adanya pembagian tugas dan tanggung jawab. Dari hasil pemetaan awal ini akan diketahui bahwa salah satu keinginan masyarakat adalah agar usaha mereka bisa meningkatkan perekonomian keluarga. Salah satu penyebab lemahnya perekonomian masyatrakat terutama para petani adalah karena dimarginalkan secara struktural. Sejak zaman Belanda sampai sekarang pengetahuan petani diisolasi hanya pada tahapan menanam bukan menjual. Artinya, pemerintah hanya mengajarkan petani bagaimana cara bercocok tanam dengan baik lalu diberikanlah aneka ragam pelatihan. Sementara pengetahuan untuk mendistribusikan/menjual secara langsung kepada konsumen tidak pernah diajarkan sehingga dengan mata rantai distribusi yang cukup panjang berdampak pada turunnya harga jual hasil panen dan menjadi tidak kompetitif bagi petani. Kalau begini caranya sampai kiamat dunia petani tidak akan berkembang dan menikmati hasil usahanya dan jadi kaya.

5. Implementasi Program Pemberdayaan. Berikan pelatihan menjual (marketing) dan seluk beluknya berdasarkan data lapangan yang terhimpun. Dan berikan pula pelatihan bagi pendamping. 
6. Perlu membangun mentalitas dan pendampingan (inkubasi) dalam bentuk monitoring dan evaluasi (Monev) secara reguler. Hal ini karena Monitoring dilakukan untuk memantau perkembangan kegiatan program, permasalahan dan hambatan yang terjadi di lapangan, tingkat pencapaian hasil yang ditargetkan, memotivasi orang-orang yang terlibat di dalamnya terus-menerus agar dinamika kerja senantiasa terjaga dan produktif. Mendokumentasikan informasi dan bahan untuk auditing agar terjaga akuntabilitasnya dan semakin terjaga pula transparansinya. Dengan begini Muzakki pun dapat melihat hasil kerja maksimal jajaran manajemen Unit Pengumpul Zakat (UPZ) di masing-masing cabang dan Ranting.

Dapat dipahami bahwa zakat profesi dan zakat produktif memberikan manfaat yang sangat besar kepada mustahiq bila dikelola dengan profesional dan penuh tanggung jawab, meskipun masih ditemukan beberapa kendala yang dapat dieliminir kegagaglannya.

\section{Penutup}

1. Pengelolaan zakat fitrah dan zakat maal dengan baik dapat mengatasi kemelaratan dan kepincangan sosial di dalam masyarakat khususnya umat Islam di Indonesia. Zakat berperan meningkatkan perekonomian Negara dan umat Islam Indonesia jika semua potensi yang ada dijalankan sesuai peraturan perundang-undangan yang ada dan petunjuk Al-Qur'an dan AsSunnah. Penelitian ini dapat memberikan kekuatan intelektual dan keimanan agar kita dapat merumuskan suatu praktik ekonomi Islam melalui Pemberdayaan Zakat Profesi dan Zakat Produktif secara konprehensif dan aplikatif dengan terus menerus berijtihad agar ia dapat down to earth sebagai bukti keimanan kita kepada Islam yang sempurna, (conprehensive way of life).

2. Dibutuhkan sosialisasi terus menerus oleh semua pihak yang ahli agar mempercepat proses pembelajaran kepada ummat yang merupakan salah satu cara efektif memberikan pemahaman kepada umat Islam agar secara bertahap 
masyarakat dapat menerima dan mempraktikkan dalam kehidupan nyata sehingga keadilan dan kesenjangan ekonomi yang menyebabkan terjadi jurang ketidakadilan yang selama ini diderita dapat terpecahkan. Dengan cara seperti ini tanpa terasa sosialisasi ekonomi Islam secara khusus dan pemberdayaan ekonomi ummat melalui pendayagunaan zakat produktif dalam realita menjadi low cost and more efficient.

3. Pengelolaan zakat di masyarakat yang mayoritas beragama Islam memberikan keyakinan bahwa Zakat dapat digunakan sebagai instrumen penting dalam pembangunan ekonomi umat Islam. Satu hal penting lain adalah membenahi setiap UPZ yang ada agar dapat menerapkan prinsip-prinsip manajemen Modern dalam pengelolaan zakat agar tercipta akuntabilitas publik dan transparansi kepada lembaga ini meningkat dan mendapatkan kepercayaan dari muzakki secara terus menerus.

\section{Referensi}

Al-Qardhawy, Yusuf: Fiqhuz Zakat, diterjemahkan oleh Salman Harun (et.al) dengan judul "Hukum Zakat", Cet VII, Bogor; Pustaka Litera Antar Nusa, 2004

Al-Qardhawy, Yusuf, Dauru al-Zakat fi 'Ilaj al-Musykilat alIqtisadiyah, diterjemahkan oleh Sari Narulita dengan judul "Spektrum Zakat dalam Membangun Ekonomi Kerakyatan", Cet, I, Jakarta, Zikrul Hakim, 2005)

Ali, Atabik dan Ahmad Zuhdi Muhdlor: Kamus Kontemporer Arab Indonesia, Cet II, Yogyakarta; Yayasan Ali Maksum Pondok Pesantren Krapyak, 1997

Ali, Muhammad Daud, Sistem Ekonomi Islam, Zakat dan Wakaf, Cet, I, Jakarta, Universitas Indonesia (UI-Press), 1988

Al-Zuhaili, Wahbah; Al-Fiqh Al-Islamy Wa Adillatuhu, Juz III, Damaskus, Daar Al-Fikr, 1997

Ash-Shiddieqy, M. Hasbi, Hukum-Hukum Fiqih Islam yang Berkembang dalam Kalangan Ahlus Sunnah, Cet, VI, Jakarta, Bulan Bintang, 1986)

Ath-Thabari, Afif Abdul Fatah: Ruh al-Din al-Islamy, Damaskus, Daar al-Fikr, 1966 
Beik, Irfan Syauqi, sebagaimana dikutip oleh Ahmad dalam Zakat Salah Satu Pilar Perekonomian Umat Masa Depan, http://masdimyati.multiply.com/journal/item/1/?\&show inter stitial $=1 \& u=\% 2 F j o u r n a l \% 2 F i t e m$

Bukhari, Imam: Shahih Bukhari Jilid III, Cet I, Semarang, Asy-Syifa, 1993

Chalil, Zaki Fuad,Wawasan Ekonomi Islam: Pemberdayaan Zakat Produktif Untuk Peningkatan Ekonomi Ummat http://kanazakat.blogspot.com/2011/07/zakat-produktifwawasan.html. Diakses tanggal 17 Desember 2011

Dahlan, Abd. Aziz (et.al): Ensiklopedi Hukum Islam Jilid III, Cet I, Jakarta; Ichtiar Baru Van Houve, 1996

Departemen Agama RI, Al-Quran dan Terjemahnya, Semarang, Toha Putra, 1989

Dewan Redaksi Ensiklopedi Islam: Ensiklopedi Islam Jilid V, Cet IV, Jakarta; Ichtiar Baru Van Houve, 1997

Glasse, Cyril: Ensiklopedi Of Islam, diterjemahkan oleh Ghafran A. Mas'adi dengan judul "Ensiklopedi Islam (Ringkas)", Cet III, Jakarta, Raja Grafindo Persada, 2002.

Hasdi, Darliansyah: Zakat dan Pajak Berkeadilan Sebuah Rekonstruksi Pemikiran Hukum Yusuf al-Qardhawi, dalam "Syariah" Jurnal Hukum dan Pemikiran No. 2 Tahun 2 JuliDesember 2002, Banjarmasin, Fakultas Syari'ah IAIN Antasari, 2002

J, Webster, \& Watson, R. T. (2002). Analyzing the Past to Prepare for the Future: Writing a Literature Review. MIS Quarterly, 26(2),

M, Zulkifli, Peranan Zakat dan Wakaf Dalam Peningkatan Ekonomi Umat Di Indonesia, http://prodibpi.wordpress.com/2010/08/05/ Diakses Tanggal, 17 Desember 2011

Mujieb, M. Abdul: Kamus Istilah Fiqih, Cet II, Jakarta; Pustaka Firdaus, 1995

Muslim, Imam, Shahih Muslim Jilid I, T.t, Dar Al-Fikr, T.th

R, Labaree, (2013). Organizing Your Social Sciences Research Paper: The Literature Review. Retrieved 22 Oktober 2015, from USC Libraries http://libguides.usc.edu/c.php?g=235034\&p=1559822 
Rais, M. Amin: Cakrawala Islam Antara Cita dan Fakta, Cet VI, Bandung, Mizan, 1995

Rasyid, Sulaiman: Fiqh Islam, Bandung; Sinar Baru, 1987

Sabiq, Sayyid: Fikih Sunnah, Cet VII, Bandung; Alma'arif, 1990

Sabuni, Muhammad Ali, Muhtasar Tafsir Ibnu Katsir, Beirut, Dar alFikr, Juz III, t.thSekretariat Negara RI, Undang-Undang No 38 Tahun 1999 Tentang Zakat, Cet, V, Bandung, Citra Umbara, 2010)

Shihab, M. Quraish: Membumikan Al-Quran Fungsi dan Peran Wahyu dalam Kehidupan Masyarakat, Cet II, Bandung, Mizan, 1992

Tim Penulis Hizbut Tahrir Indonesia, Menegagkkan Syariat Islam, Cet.I; Hizbut Tahrir Indonesia, 2002

Y, Levy, \& Ellis, T. J. (2006). A Systems Approach to Conduct an Effective Literature Review in Support of Information Systems Research. Informing Science, 9, 181-212

*Dosen Fakultas Ushuluddin, Adab dan Dakwah IAIN Palu 